\title{
Phototoxic action of light emitting diode in the in vitro viability of Trichophyton rubrum
}

\author{
Ação fototóxica do diodo emissor de luz na viabilidade de Trichophyton \\ rubrum in vitro
}

José Cláudio Faria Amorim ${ }^{1}$

Orley Araújo Alves ${ }^{3}$

Gerdal Roberto Sousa ${ }^{5}$

André Costa Cruz Piancastelli ${ }^{6}$

\author{
Betania Maria Soares ${ }^{2}$ \\ Marcus Vinícius Lucas Ferreira ${ }^{4}$ \\ Lívio de Barros Silveira \\ Marcos Pinotti ${ }^{7}$
}

\begin{abstract}
BACKGROUND - Trichophyton rubrum is the most common agent of superficial mycosis of the skin and nails causing long lasting infections and high recurrence rates. Current treatment drawbacks involve topical medications not being able to reach the nail bed at therapeutic concentrations, systemic antifungal drugs failing to eradicate the fungus before the nails are renewed, severe side effects and selection of resistant fungal isolates. Photodynamic therapy (PDT) has been a promising alternative to conventional treatments.

OBJECTIVES: This study evaluated the in vitro effectiveness of toluidine blue O (TBO) irradiated by Light emitting diode (LED) in the reduction of T. rubrum viability.

METHODS: The fungal inoculums' was prepared and exposed to different TBO concentrations and energy densities of Light emitting diode for evaluate the T. rubrum sensibility to PDT and production effect fungicidal after photodynamic treatment. In addition, the profiles of the area and volume of the irradiated fungal suspensions were also investigated.

RESULTS: A small reduction, in vitro, of fungal cells was observed after exposition to $100 \mu \mathrm{M}$ toluidine blue $\mathrm{O}$ irradiated by $18 \mathrm{~J} / \mathrm{cm}^{2} \mathrm{Light}$ emitting diode. Fungicidal effect occurred after $25 \mu \mathrm{M}$ toluidine blue $\mathrm{O}$ irradiation by Light emitting diode with energy density of $72 \mathrm{~J} / \mathrm{cm}^{2}$. The analysis showed that the area and volume irradiated by the Light emitting diode were $52.2 \mathrm{~mm}^{2}$ and $413.70 \mathrm{~mm}^{3}$, respectively.

ConcLusions: The results allowed to conclude that Photodynamic therapy using Light emitting diode under these experimental conditions is a possible alternative approach to inhibit in vitro T. rubrum and may be a promising new treatment for dermatophytosis caused by this fungus. Keywords: Antifungal agents; Onychomycosis; Photochemotherapy

Resumo: FunDAMENTOS - Trichophyton rubrum é o agente mais comum das micoses superficiais de pele e unhas causando infecções de longa duração e altas taxas de recidiva. As desvantagens do tratamento atual envolvem medicações tópicas as quais não são capazes de alcançar o leito ungueal em concentrações terapêuticas, antifúngicos sistêmicos que não erradicam o fungo antes das unhas serem renovadas, efeitos colaterais graves e seleção de isolados fúngicos resistentes. A terapia fotodinâmica tem sido uma alternativa promissora aos tratamentos convencionais.

OBjetrvos - Este estudo avaliou a eficácia, in vitro, de azul de orto-toluidina irradiado por diodo emissor de luz na redução da viabilidade de T. rubrum. MÉTodos: O inóculo fúngico foi preparado e exposto a diferentes concentrações de azul de orto-toluidina e densidades de energia do diodo emissor de luz, para avaliar a sensibilidade de T. rubrum e o efeito fungicida, após terapia fotodinâmica. Além disso, os perfis da área e volume das suspensões fúngicas irradiados também foram investigados.

RESULTADOS: Uma pequena redução, in vitro, de células fúngicas foi observada após a exposição a $100 \mathrm{mM}$ azul de orto-toluidina irradiados por diodo emissor de luz a $18 \mathrm{~J} / \mathrm{cm}^{2}$. Efeito fungicida ocorreu após irradiação $25 \mu \mathrm{M}$ orto-toluidina por diodo emissor de luz com densidade de energia de $72 \mathrm{~J} / \mathrm{cm}^{2}$. A análise mostrou que a área e o volume irradiados pelo diodo emissor de luz foram 52,2 $\mathrm{mm}^{2} \mathrm{e} 413,70 \mathrm{~mm}^{3}$, respectivamente. CONCLUSÕES Os resultados permitiram concluir que a terapia fotodinâmica com diodo emissor de luz, nas condições experimentais é uma abordagem alternativa para inibir, in vitro, T. rubrum e pode ser um tratamento promissor para as dermatofitoses causadas por este fungo.

Palavras-chave: Antimicóticos; Fotoquimioterapia; Onicomicose
\end{abstract}

Received on 26.01.2011

Approved by the Advisory Board and accepted for publication on 01.01.2011

* Work performed at the Department of Mechanical Engineering, Bioengineering Laboratory of the Universidade Federal de Minas Gerais (DEMEC - Lab-Bio - UFMG) Belo Horizonte (MG), Brazil.

Conflict of interest: none

Financial Support: Coordination and Improvement of Tertiary Personnel (Coordenação de Aperfeiçoamento de Pessoal de Nível Superior - CAPES), National Council of Scientific and Technological Development (Conselho Nacional de Desenvolvimento Científico e Tecnológico (CNPq) and Foundation of Research Support of the Estado de Minas Gerais (Fundação de Amparo à Pesquisa do Estado de Minas Gerais (FAPEMIG).

$\mathrm{PhD}$ in Bioengineering - Professor at the Universidade de Itaúna (UI) - Itaúna (MG), Brazil.

PhD - Post Doctorate candidate in Mechanic Engineering and teacher. Departament of Mechanical Engineering, Bioengineering Laboratory of the Universidade Federal de Minas Gerais (DEMEC - Lab-Bio - UFMG) - Universidade de Itaúna (UI) - Itaúna (MG), Brazil.

Master in Bioengineering - Post Doctorate candidate in Bioengineering. Departament of Mechanical Engineering, Bioengineering Laboratory of the Universidade Federal de Minas Gerais (DEMEC - Lab-Bio - UFMG) - Belo Horizonte (MG), Brazil.

$\mathrm{PhD}$ in Bioengineering - Post Doctorate candidate in Mechanic Engineering and teacher. Departament of Mechanical Engineering, Bioengineering Laboratory of the Universidade Federal de Minas Gerais (DEMEC - Lab-Bio - UFMG) - Belo Horizonte (MG), Brazil.

$\mathrm{PhD}$ in Bioengineering - Professor at the Administrative Studies - Centro de Estudos de Odontologia - FEAD - Belo Horizonte (MG), Brazil.

Dermatologist - Coordinator of the Dermatology Service of the Hospital da Polícia Militar de Minas Gerais (HPM - MG) - Belo Horizonte (MG), Brazil.

$\mathrm{PhD}$ in Mechanical Engineering - Supervisor and teacher. Departament of Mechanical Engineering, Bioengineering Laboratory of the Universidade Federal de Minas Gerais (DEMEC - Lab-Bio - UFMG) - Belo Horizonte (MG), Brazil. 


\section{INTRODUCTION}

Dermatophytes can causes mycosis known as dermatophytosis or tinea of the skin, hair and nails due to its ability to utilize keratin as carbon source. It infects humans across the world, with variable frequency and epidemiology. ${ }^{1,2}$ Trichophyton rubrum was found to be the most common agent of superficial mycosis in Brazilian epidemiological studies. ${ }^{2-4}$ This species often correlates with the infected host for a prolonged periods, increasing the likelihood of transmission of infection to new hosts. The high prevalence of dermatophytosis is due mainly to the high human and animal reservoirs existence and its high inherent resistance to adverse environmental conditions. ${ }^{5}$

The conventional treatment involves topical formulations for mild initial infections and, in widespread cases, the use of systemic medications such as itraconazole and terbinafine. In onychomycosis, depending on the thickness of the nail plate, neither topical nor systemic drugs are able to reach the site of infection, causing low cure rates and frequent relapses. Moreover, pharmacological interactions of systemic medications, fungal resistance and low patient compliance also contribute to the high rate of unsuccessful treatments. ${ }^{1,6}$

It has become clear that it is necessary to develop new safe and effective treatments, especially for onychomycosis. Photodynamic therapy (PDT) is a promising alternative to conventional treatments. It consists of the activation of nontoxic photosensitizers by visible light of an appropriate wavelength inducing chemical changes in neighboring molecules through two pathways known as Type I and Type II. In Type-I photochemical mechanism there is the transfer of electrons or hydrogen atom to oxygen or other adjacent molecules to form radicals and reactive oxygen species (superoxide anions, hydrogen peroxide, hydroxyl radical) which can attack and oxidize any molecule within the cell. Hydroxyl radicals and hydrogen peroxide easily diffuse through membranes, thus the damage is not limited to one cellular compartment. In Type II photochemical process, during energy transfer, singlet oxygen is formed and can oxidize biological molecules as proteins, nucleic acids and lipids, irreversibly altering cellular vital components and resulting in oxidative lethal damage. ${ }^{7.8}$

Toluidine blue $\mathrm{O}$, a phenothiazine dye, binds preferably to the cell membrane as its main target. During dark incubation, the positively charged dye binds to negatively charged cell surface and remains outside of the cytoplasmatic membrane. After illumination, changes to the physical properties of the membrane are induced by depletion of ergosterol and the accumulation of polar derivatives, ultimately allowing small quantities of photosensitizer to cross the cell membrane and leading to inactivation of intracellular enzymes and the disruption of metabolism. The barrier function of the cytoplasmic membrane is lost, and its capacity to transport sugars, amino acids and phosphate is inhibited. ${ }^{9-11}$

In the present study, we evaluated in vitro photodynamic inactivation of $T$. rubrum using toluidine blue $\mathrm{O}$ (TBO) as a photosensitizer and light emitting diode (LED) and laser as light sources.

\section{MATERIALS AND METHODS}

Organism: We tested a Trichophyton rubrum reference strain (INCQS 40051) from the culture collection of the University of Georgia, Atlanta, GA, USA. The isolate was maintained during experiments by subculture every 7 days on Sabouraud Dextrose Agar (SDA, Difco Laboratories, Sparks, MD, USA) at $28^{\circ} \mathrm{C}$.

Photosensitizer: The photosensitizer (PS) used was toluidine blue O (TBO) (Sigma, St. Louis, MO., USA) at 100 and $25 \mu \mathrm{M}$. The solution was prepared in sterile distilled water and stored at $4^{\circ} \mathrm{C}$ in the dark

Light source: In this study we used one equipment - a $630 \mathrm{~nm}( \pm 10 \mathrm{~nm}$ ) LED (Fisioled, MMoptics, SP, Brazil) with variable fluency $\left(18-90 \mathrm{~J} / \mathrm{cm}^{2}\right)$ and irradiation time (3, 9, 12 e 15 minutes).

\section{Photodynamic inactivation in Trichophyton rubrum}

Inoculums' preparation: T. rubrum INCQS 40051 was subcultured in SDA and incubated at $28^{\circ} \mathrm{C}$ for 7 days, which corresponds to the exponential growth phase. Colonies were covered with $5 \mathrm{~mL}$ of sterile saline, rubbed carefully with sterile loop and the transmittance of the suspensions was adjusted to $65-70 \%$ at $530 \mathrm{~nm}$, which corresponds to a final inoculum of $0.5-5 \times 10^{6}$ cells $/ \mathrm{mL} .^{12}$

Test procedure: For these tests were used $\mathrm{TBO}$ at $100 \mu \mathrm{M}$, energy density $\left(18 \mathrm{~J} / \mathrm{cm}^{2}\right)$ (irradiation time of 3 minutes) for LED. The resonance with this PS and the light emitted by the equipment was verified by spectroscopic analysis between 400 to $900 \mathrm{~nm}$. The cell suspensions were prepared as described, equally divided into $10 \times 10 \mathrm{~mm}$ glass tubes (final suspension volume of $1000 \mu \mathrm{L}$ in each tube) and identified. In the groups treated with light, the glass tubes were irradiated from bottom to top. The control experiments were: untreated, without LED irradiation (L) and photosensitizer (PS) (L-PS-); irradiated by LED without photosensitizer (L+PS-) and exposed to TBO without light irradiation (L-PS+). For the groups treated with PDT, $100 \mu \mathrm{L}$ of TBO was added to $900 \mu \mathrm{L}$ of fungal suspension, incubated for 5 minutes in the dark and then irradiated by LED $(\mathrm{L}+\mathrm{PS}+)$. After the treatment, the suspensions were diluted and subcultured in Petri dis- 
hes containing SDA, incubated at $28^{\circ} \mathrm{C}$ for 4 days, and the colonies were counted (Figure 1). In addition, microscopic examination was performed to observe the photosensitizer association with the yeast surface.

Evaluation of photodynamic therapy (PDT) fungicidal effect in Trichophyton rubrum: the experimental conditions were optimized to establish the lowest value of energy density able to cause $100 \%$ reduction of cellular viability (fungicidal effect) after PDT using TBO at $25 \mu \mathrm{M}$ and different LED fluencies $\left(54-90 \mathrm{~J} / \mathrm{cm}^{2}\right) .{ }^{13}$ The control experiments were divided in groups: untreated fungal suspension (L-PS-); irradiation by LED without photosensitizer with fluencies of $54 \mathrm{~J} / \mathrm{cm}^{2}$ (L54+PS-), 72 $\mathrm{J} / \mathrm{cm}^{2}$ (L72+PS-) and $90 \mathrm{~J} / \mathrm{cm}^{2}$ (L90+PS-), and tubes with $25 \mu \mathrm{M}$ TBO incubated for 5 minutes in the dark (L-PS+) without light emission. Irradiation of TBO by LED energy density of $54 \mathrm{~J} / \mathrm{cm}^{2}$ (L54+PS+), $72 \mathrm{~J} / \mathrm{cm}^{2}$ (L72+PS+) and $90 \mathrm{~J} / \mathrm{cm}^{2}$ (L90+PS+) with $25 \mu \mathrm{M}$ TBO were the groups treated by PDT.

All tests were repeated three times for reproducibility and the experiments were carried out at room temperature. To minimize any interfering factors, the experiments were performed in the dark due to dye photosensitivity; the volume in the tubes was verified during tests to check for a possible volatilization of the reagents, and fungal growth controls were compared after diluting to a concentration corresponding to the initial inoculum.

Analysis of suspension area and volume irradiated with LED: in order to evaluate the LED phototoxic activity in T. rubrum, the irradiated area

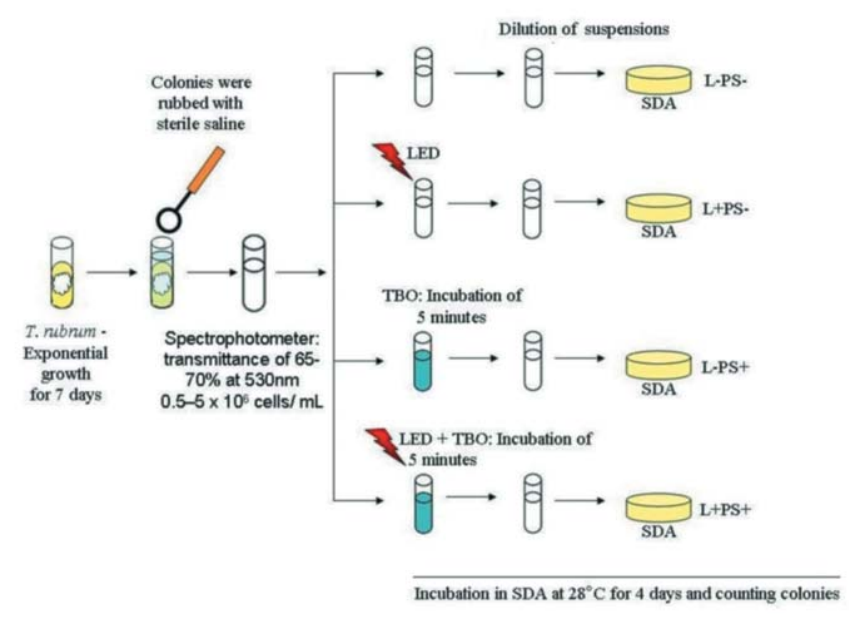

FIGURE 1: Experimental protocol of in vitro photodynamic therapy (PDT) in Trichophyton rubrum (INCQS 40051). Control without any treatment (L-PS-); Light Emitting Diode (LED) irradiation with energy density of $18 \mathrm{~J} / \mathrm{cm}^{2}$ without toluidine blue $\mathrm{O}(\mathrm{TBO})$

(L+PS-); TBO at $100 \mu \mathrm{M}$ without LED irradiation (L-PS+); irradiation of TBO by LED energy density of $18 \mathrm{~J} / \mathrm{cm} 2(\mathrm{~L}+\mathrm{PS}+)$ SDA - Sabouraud Dextrose Agar and volume were calculated. For these tests, the dimensional data of glass tubes were considered. The test tubes were photographed and the area with greater absorption of light by the PS was calculated through the software Laser.exe, developed by the LABBIO (Bioengineering Laboratory, Universidade Federal de Minas Gerais) in order to obtain a measurement in pixels. The images were then exported to the software Solidworks 2006, so that solids of revolution corresponding to these images were generated and the volume of irradiated areas calculated.

Statistical Analysis: The results obtained were organized and analyzed by non-parametric statistical tests using a $\mathrm{p}$ value equal to $0.05 .^{14}$

\section{RESULTS}

The analysis of TBO absorption showed that this PS is resonant with the light emitted by LED (Graph 1). Under optical microscopic examination, fungal cells appeared blue, indicating that the 5 minutes exposure to TBO was sufficient to coat the surface (Figure 2). With a 95\% confidence interval, the statistical tests demonstrated no significant difference $(p>0.05)$ between the groups (control for yeast growth untreated cells, LED irradiation of $18 \mathrm{~J} / \mathrm{cm}^{2}$ without TBO exposition and $100 \mu \mathrm{M} \mathrm{TBO}$ without irradiation). Therefore, the actions of light or TBO alone did not reduce cell viability of T. rubrum (Table 1). Cells treated with PDT, however, showed statistically significant difference $(\mathrm{p}$ $<0.05$ ) compared to experimental controls, but a small reduction of fungal cells was observed (average

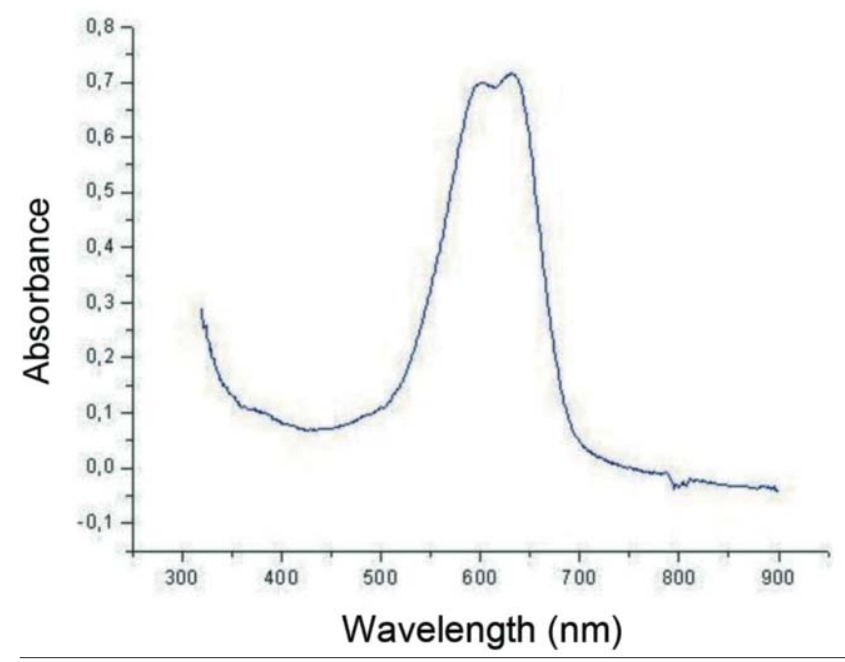

GRAPH 1 - Trichophyton rubrum (INCQS 40051) with $100 \mu \mathrm{M}$ toluidine blue $\mathrm{O}$ (TBO) after 5 minutes of incubation in the dark 
TABLE 1: Effect of photodynamic therapy (PDT) in reduction (R) of Trichophyton rubrum viable cells number for each treatment group

\begin{tabular}{lccc}
\hline Treatments & $\begin{array}{c}\text { Median Log10 } \\
\text { viable cells/mL }\end{array}$ & $\begin{array}{l}\text { R range Log10 } \\
\text { viable cells } / \mathbf{m L}\end{array}$ & $\begin{array}{l}\text { Reduction Median } \\
\text { Log10 cells/mL }\end{array}$ \\
\hline L-PS- & $6.22^{\mathrm{a}}$ & $6.08-6.34^{\mathrm{a}}$ & $0^{\mathrm{a}}$ \\
L+PS- & $6.20^{\mathrm{a}}$ & $6.00-6.43^{\mathrm{a}}$ & $0^{\mathrm{a}}$ \\
L-PS+ & $6.22^{\mathrm{a}}$ & $6.08-6.36^{\mathrm{a}}$ & $0^{\mathrm{a}}$ \\
L+PS+ & $4.50^{\mathrm{b}}$ & $5.30-6.08^{\mathrm{b}}$ & $1.72^{\mathrm{b}}$ \\
\hline
\end{tabular}

L-PS-: control without any treatment; L+PS-: Light Emitting Diode (LED) energy density of $18 \mathrm{~J} / \mathrm{cm}^{2}$ without photosensitizer (PS) toluidine blue O (TBO); L-PS+: $100 \mu \mathrm{M}$ TBO without light irradiation; L+PS+: TBO irradiation by LED (PDT) with $100 \mu \mathrm{M}$ TBO (PDI). $a$ - equivalent values $(p>0.05), b-$ Significantly different values, considering $(p<0.05)$. $R$ - Reduction of viable cells.

of $1.72 \log _{10}$ ) (Table 1). The results of evaluation of fungicidal effects showed no significant difference $(p>0.05)$ between controls G1 to G5 (control for fungal growth untreated cells, different energy density by LED without TBO exposition and $25 \mu \mathrm{M}$ TBO without LED irradiation) (Graph 2). However, in groups treated with PDT a significant reduction of $T$. rubrum viability was observed ( $4.30 \log _{10}$ for $54 \mathrm{~J} / \mathrm{cm}^{2}$ and $4.00 \log _{10}$ for $90 \mathrm{~J} / \mathrm{cm}^{2}$ ). Total inhibition of cell growth occurred after TBO irradiation by LED for 12 minutes of irradiation time ( 72 $\mathrm{J} / \mathrm{cm}^{2}$ ) (Graph 2). The analysis of area and volume of irradiation showed that the area irradiated by the LED was $52.2 \mathrm{~mm}^{2}$ and the volume of suspension irradiated by LED was $413.70 \mathrm{~mm}^{3}$ (Figure 3).

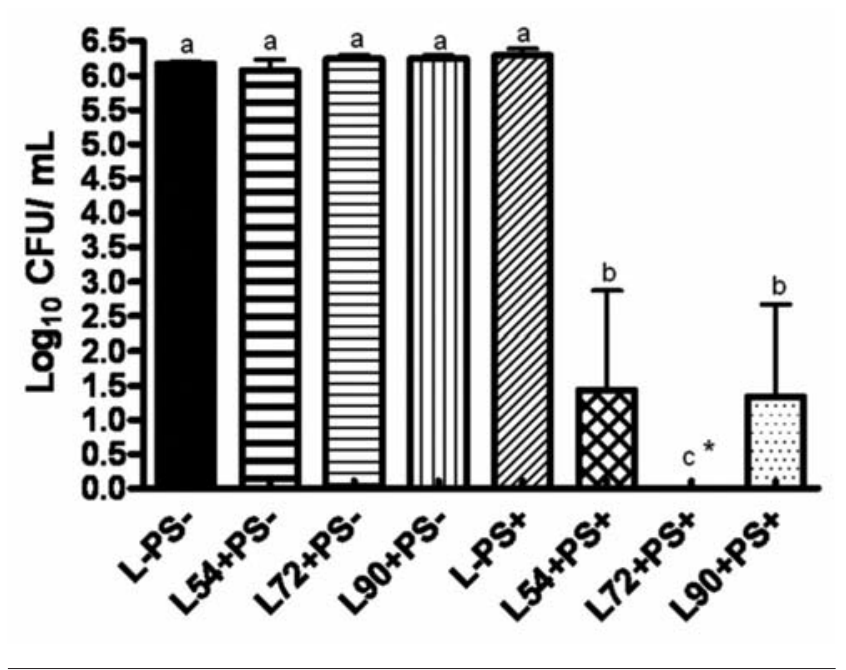

GrAPH 2 - Effect of photodynamic therapy (PDT) in Trichophyton rubrum (INCQS 40051) survival for each treatment group. Control without any treatment (L-PS-); Light Emitting Diode (LED) irradiation with energy density of $54 \mathrm{~J} / \mathrm{cm}^{2}$ (L54+PS-), $72 \mathrm{~J} / \mathrm{cm}^{2}$ (L72+PS-), $90 \mathrm{~J} / \mathrm{cm}^{2}$ (L90+PS-); TBO at $25 \mu \mathrm{M}$ (L-PS+); irradiation of TBO by LED energy density of $54 \mathrm{~J} / \mathrm{cm}^{2}$ (L54+PS+),72 J/cm $\mathrm{cm}^{2}$ (L72+PS+), $90 \mathrm{~J} / \mathrm{cm}^{2}$ (L90+PS+) with $25 \mu \mathrm{M}$ TBO (PDT). a - equivalent values $(p>0.05)$. b, c - Significantly different values, considering $(\mathrm{p}<0.05) . *$ fungicidal effect

\section{DISCUSSION}

The emergence of fungal diseases has been considered a public health problem because it can affect both immune suppressed hospitalized individuals as susceptible persons in the community, with high rates of morbidity, mortality and financial costs. Therefore, the antifungal efficacy of photodynamic therapy has been tried and evaluated using different photosensitizers (5-aminolevulinic acid - ALA, methylene blue, toluidine blue $\mathrm{O}$, porphyrins) and light sources (lamps with filters, Laser, LEDs) for Candida spp., Cryptococcus neoformans, Trichophyton rubrum, Metarbizium anisopliae and Aspergillus nidulans. ${ }^{13,15,16}$ This study evaluated the efficacy of photodynamic therapy using TBO irradiated by LED in reduction of T. rubrum viability.

Smijs et al. reported complete inactivation of T. rubrum spores and destruction of the hyphae using porphyrins (DP mme, Sylsens B) activated by broadband white and red light. Later, in an ex vivo model, the same group of researchers observed that PDT is more effective in the early stages of germination of microconidia of T. rubrum then after the formation of hyphae and demonstrated that morphological changes such as wall deformations, leakage of internal cell material, structure of the hyp-

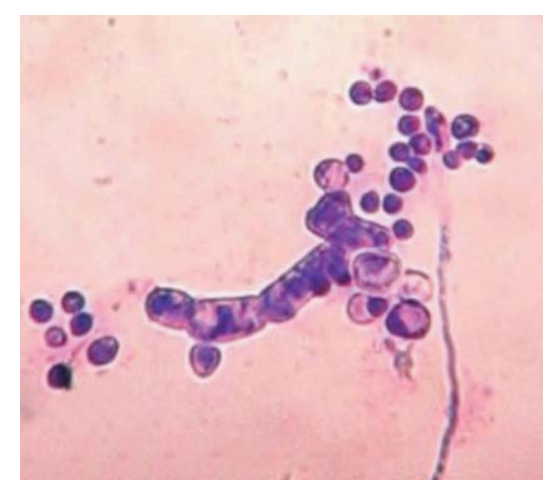

FIGURE 2 -

Trichophyton rubrum (INCQS 40051) with $100 \mu \mathrm{M}$ toluidine blue O (TBO) after 5 minutes of incubation in the dark (original dimensions: $1999 \mathrm{x}$ 2792 pixels) 


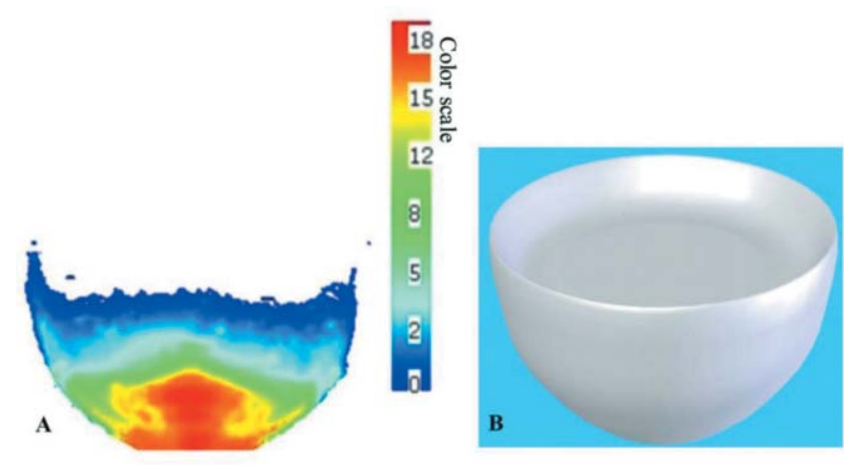

Figure 3 - Analysis of area (A) and volume (B) of Trichopbyton rubrum (INCQS 40051) suspension in glass tubes irradiated by Light emitting diode

hal wall with rough appearance, bulge formation and a ruptured hyphal wall small smooth appearing occurred after the photodynamic treatment. ${ }^{17,18}$ These authors showed that the photosensitizer Sylsens B did not penetrate the fungal cell wall when the photodynamic inhibition (IFD) was unsuccessful, and the opposite happened exactly after irradiation of light with a successful photodynamic process, showing that the dye penetrates the cell interior. $^{19,20}$

The selection of an effective photosensitizer is critical to the success of PDT. It should have a safe molecular profile in humans, it needs to absorb the light at a compatible wavelength and must produce a high excitation efficiency. ${ }^{21}$ Photosensitizer dyes with the absorption band at the resonant wavelength emitted by LEDs increase the efficiency of this therapy, allowing to treat increasingly deeper infections without the need for multiple irradiation sessions. ${ }^{22}$

In this paper, we utilized TBO at 100 and 25 $\mu \mathrm{M}$ because it's nontoxic in the dark to the microorganism tested, presented an absorption band resonant with the light wavelength produced by equipments used and easily associated with the fungal cell surface. TBO at $100 \mu \mathrm{M}$ causes reduction of fungal growth, but fungicidal effect was observed using a lesser TBO concentration $(25 \mu \mathrm{M})$. Later, we demonstrated that TBO at $25 \mu \mathrm{M}$ causes high reduction of Candida albicans after LED irradiation compared with higher concentrations $(100$ and $50 \mu \mathrm{M}) .{ }^{13}$ According to Jackson et al., at higher TBO concentrations, photodynamic inactivation would be less efficient because the photosensitizer target sites would become saturated, leaving a substantial pool of unbounded TBO that can absorb photons of light away from TBO associated with cells. ${ }^{23}$

Lasers and LEDs have been used in various therapies. The possibility of using PDT in the red spec- trum for dermatophytosis should be considered, because this spectrum of light is not absorbed by hemoglobin and can penetrate more deeply into the living tissue. This property is particularly important in the treatment of nail infections, often refractory to conventional therapy. ${ }^{13}$ The LED is compact, requires less energy to emit light with the desired wavelengths, does not produce thermal damage in biological tissues $^{18}$ and has been manufactured in various wavelengths $(630,670$ and $690 \mathrm{~nm}){ }^{24,25}$

The equipment tested in this report was effective in reducing the T. rubrum viability in fungal suspension. The LED irradiated area of $52.2 \mathrm{~mm}^{2}$ and volume of $413.7 \mathrm{~mm}^{3}$ showed high inhibition of viable fungal cells plus fungicidal effect. This occurred because the light emitted by the LED clusters is divergent allowing a wider treatment area. ${ }^{26,27}$

In this study, increase of energy density and time of irradiation showed improvement of T. rubrum photoinactivation efficiency. Prates et al. observed that longer exposure times were more effective than short times to generate reactive oxygen species and is more effective in inhibiting the growth of Candida albicans. Qin et al. showed that an upper limit of photonic effects is observed because the photosensitizer does not absorb all light excess. ${ }^{15,28}$

Clinical studies have demonstrated the efficacy of PDT in the treatment of superficial mycoses. Calzavara-Pinton et al. described a successful and well tolerated treatment of interdigital Tinea pedis with PDT, using 29\% ALA in Eucerin cream, pre-irradiation period of four hours and $75 \mathrm{~J} / \mathrm{cm}^{2}$ irradiation with light in the red spectrum. However, four patients had recurrence of the mycosis after 4 weeks of therapy. ${ }^{29}$ Watanabe et al. succeeded in treating two clinical cases of onychomycosis with PDT after treatment with urea at $20 \%$ per 10 hours, using cream of $20 \%$ ALA, with pre-irradiation time of five hours, and irradiation of $100 \mathrm{~J} / \mathrm{cm}^{2}$ laser at $630 \mathrm{~nm} \cdot{ }^{30}$ Clinical and microbiological cures were observed after seven sessions for the first patient, and six sessions for the second patient. After six and three months respectively, there was no recurrence of the mycosis. Both patients reported tolerable soreness during irradiation.

Sotiriou et al. treated 30 patients with onychomycosis using ALA irradiated by red light (570-670 $\mathrm{nm})$ from a non-coherent light source in three sessions and observed that 13 patients (43.3\%) were cured at month 18 , and one year after the cure rate dropped to $36.6 \% .^{16}$ Experimental tests using others photosensitizers as TBO and non-coherent light source as LED are extremely important because TBO irradiated by LED can be an inexpensive solution when compared to the use of other sensitizers such as ALA in conjunction with Laser. 


\section{CONCLUSION}

The present study shows that PDT has an effective T. rubrum fungicidal activity in vitro and TBO irradiated by LED can reduce fungal growth. It also demonstrated that a lower concentration of photosensitizer and higher energy density were essential conditions to obtain maximal fungicidal effect.

\section{REFERENCES}

1. Gupta AK, Cooper EA. Update in antifungal therapy of dermatophytosis, Mycopathologia. 2008;166:353-67.

2. Aquino VR, Constante CC, Bakos L. Frequência das dermatofitoses em exames micológicos em Hospital Geral de Porto Alegre, Brazil. An Bras Dermatol. 2007;82: 23944.

3. Damázio PMRBC, Lacerda HR, Lacerda Filho AM, Magalhães OMC, Neves RP. Epidemiologia, etiologia e formas clínicas das dermatoftoses em Pernambuco, 1995-2005. Rev Soc Bras Med Trop 2007:40:484-6.

4. Rezende C, Borsari GP, Silva ACF, Cavalcanti FR. Estudo epidemiológico das dermatofitoses em instituições públicas da cidade de Barretos, São Paulo, Brazil. RBAC. 2008;40:13-6.

5. Dahdah M., Scher RK. Dermatophytes. Curr Fungal Infect Rep. 2008;2:81-86.

6. Manzano-Gayosso P, Méndez-Tovar LJ, Hernández-Hernández F, López-Martínez R. Antifungal resistance: an emerging problem in México. Gac Med Mex. 2008; 144: 23-26.

7. Maisch T. A new strategy to destroy antibiotic resistant microorganisms: antimicrobial photodynamic treatment. Mini Rev Med Chem. 2009;9:974-83.

8. Plaetzer K, Krammer B, Berlanda J, Berr F, Kiesslich T. Photophysics and photochemistry of photodynamic therapy: fundamental aspects. Lasers Med Sci. 2009; 24:25968.

9. Ito T. Toluidine blue: the mode of photodynamic action in yeast cells. Photochem. Photobiol. 1997;25:47-53.

10. Böcking T, Barrow KD, Netting AG, Chilcott TC, Coster HGL, Höfer M. Effects of singlet oxygen on membrane sterols in the yeast Saccharomyces cerevisiae. Eur $\mathrm{J}$ Biochem. 2000;267:1607-18.

11. Paardekooper M, De Bruijne AW, Van Steveninck J, Van den Broek PJ. Intracellular damage in yeast cells caused by photodynamic treatment with toluidine blue. Photochem Photobiol. 1995;61:84-9.

12. da Silva Barros ME, de Assis Santos D, Hamdan JS. Evaluation of susceptibility of Trichophyton mentagrophytes and Trichophyton rubrum clinical isolates to antifungal drugs using a modified CLSI microdilution method (M38-A). J Med Microbiol. 2007:56:514-8

13. Soares BM, da Silva DL, Sousa GR, Amorim JC, de Resende MA, Pinotti M, et al. In vitro photodynamic inactivation of Candida spp. growth and adhesion to buccal epithelial cells. J Photochem Photobiol B. 2009;94:65-70.

14. Sampaio IBM. Estatística aplicada à experimentação animal. 2. ed. Belo Horizonte: FEPMVZ; 2002.

15. Prates RA, Silva EG, Yamada Jr. AM, Suzuki LC, Paula CR, Ribeiro MS. Light parameters influence cell viability in antifungal photodynamic therapy in a fluence and rate fluence-dependent manner. Laser Physics. 2009;19:1038-44.

16. E. Sotiriou T, Koussidou-Ermonti G, Chaidemenos Z, Apalla D, Ioannides D. Photodynamic therapy for distal and lateral subungual toenail onychomycosis caused by Trichophyton rubrum: preliminary results of a single-centre open trial. Acta. Derm. Venereol. 2010;90:216-7.

17. Smijs TGM, Schuitmaker HJ. Photodynamic inactivation of the dermatophyte Trichophyton rubrum. Photochem. Photobiol. 2003;77:556-60.

18. Smijs TG, van der Haas RN, Lugtenburg J, Liu Y, de Jong RL, Schuitmaker HJ. Photodynamic treatment of the dermatophyte Trichophyton rubrum and its microco- nidia with porphyrin photosensitizers. Photochem. Photobiol. 2004;80:197-202.

19. Smijs TGM, Bouwstra JA, Schuitmaker HJ, Talebi M, Pavel S. A novel ex vivo skin model to study the susceptibility of the dermatophyte Trichophyton rubrum to photodynamic treatment in different growth phases. J Antimicrobial Chemother. 2007:59:433-40.

20. Smijs TGM, Mulder AA, Pavel S, Onderwater JJM, Koerten HK, Bouwstra JA Morphological changes of the dermatophyte Trichophyton rubrum after photodynamic treatment: a scanning electron microscopic study. Med Mycol. 2008;46:315-25

21. Chan $\mathrm{Y}$, Lai $\mathrm{CH}$. Bactericidal effects of different laser wavelengths on periodontopathic germs in photodynamic therapy. Lasers Med. Sci. 2003;18:51-5.

22. 22. Jori G. Photodynamic therapy of microbial infections: state of the art and perspectives. J Environ Pathol Toxicol Oncol. 2006;25:505-20.

23. Jackson Z, Meghii S, Macrobert A, Henderson B, Wilson M. Killing of the yeast and hyphal forms of Candida albicans using a light-activated antimicrobial agent. Lasers Med Sci. 1999;14:150-7.

24. Mang T.S. Lasers and light sources for PDT: past, present and future. Photodiag. Photodyn. Ther. 2004;1:43-8.

25. Vladimirov YA, Osipov AN, Klebanov Gl. Photobiological principles of therapeutic applications of laser radiation. Biochemistry (Mosc). 2004;69:81-90.

26. Sthal F, Ashworth SH, Jandt KD, Mills RW. Light-emitting diode (LED) polymerization of dental composites: flexural properties and polymerization potential. Biomaterials. 2000;21:1379-85

27. Hamblin MR, Demidova TN. Mechanisms of low level light therapy. Proc SPIE. 2006:6140:1-12.

28. Qin Y, Luan X, Bi L, He G, Bai X, Zhou C, et al. Toluidine blue-mediated photoinactivation of periodontal pathogens from supragingival plaques. Lasers Med. Sci 2008; 23: $49-54$.

29. Calzavara-Pinton PG, Venturini M, Capezzera R, Sala R, Zane C. Photodynamic therapy of interdigital mycoses of the feet with topical application of 5-aminolevulinic acid. Photodermatol. Photoimmunol. Photomed 2004;20:144-7.

30. Watanabe D, Kawamura C, Masuda Y, Akita Y, Tamada Y, Matsumoto Y. Success treatment of toenail onychomycosis with photodynamic therapy. Arch Dermatol. 2008;144:19-21.

MAILING ADDRESS:

Betania Maria Soares

Av. Antônio Carlos, 6627

Belo Horizonte -

31270-901 Minas Gerais MG, Brazil

Phone: 31 3409-6677 - Fax: + 55 + $313443-3783$.

E-mail:bmsoares@gmail.com

How to cite this article: Amorim JCF, Soares BM, Alves OA, Ferreira MVL, Sousa GR, Silveira LB, Piancastelli ACC, Pinotti M. Phototoxic action of light emitting diode in the in vitro viability of Trichophyton rubrum. An Bras Dermatol. 2012;87(2):250-5. 